\title{
OPTIMALISASI PERAN WAKAF DALAM PEMBERDAYAAN USAHA MIKRO, KECIL DAN MENENGAH (UMKM)
}

\author{
Sri Budi Cantika Yuli \\ Pascasarjana Fakultas Ekonomi dan Bisnis Universitas Airlangga \\ E-mail: cantikayuli@yahoo.com
}

\begin{abstract}
The potential of Zakat, Infaq, Shodaqoh (ZIS), and Waqaf (endowments) to help society economic improvement are very important, yet the role of Islamic Finance Institution, as the executing agency that administer these four pious deed, were still not optimal yet. This article reveals the important role of Endowments in assisting the empowerment of Micro, Small, and Medium Enterprises (MSMEs) which is one of the strengths in poverty alleviation, employment creation and increase the strength of family income. Waqaf (endowments) Management Institute, an organization that empowers MSMEs through microfinance and business assistance, offers some strategic steps that must be carried out in managing successful business namely providing investment capital and working capital, presenting training and skills improvement, business consulting, improving product quality, market, business networking, and technology.
\end{abstract}

Keywords: Zakat, Infaq and Shodaqoh (ZIS), Waqaf, MSMEs, Microfinance

\begin{abstract}
Abstrak
Peran Lembaga Keuangan Publik Islam yang mengelola zakat, Infaq Shodaqoh dan (ZIS) dan Wakaf di kesejahteraan masyarakat Indonesia tidak optimal, sedangkan potensi ZIS dan Wakaf mungkin eksekusi. Artikel ini membahas tentang peran Wakaf dalam pemberdayaan Usaha Mikro, Kecil dan Menengah (UMKM). UMKM dapat menjadi kekuatan dalam pengentasan kemiskinan, penciptaan lapangan kerja dan kekuatan dalam meningkatkan pendapatan keluarga. Lembaga Manajemen Wakaf dapat memberdayakan UMKM melalui pembiayaan mikro dan bantuan usaha. Langkah-langkah strategis yang harus dilakukan adalah untuk memberikan modal investasi dan modal kerja, memberikan pelatihan dan keterampilan perbaikan, konsultasi bisnis, meningkatkan kualitas produk, pasar, jaringan bisnis, dan teknologi.
\end{abstract}

Kata Kunci: Zakat, Infaq dan Shodaqoh (ZIS), Wakaf, UMKM, Micro Finance

Terdapat beberapa model instrumen keuangan Islam guna menjamin kesejahteraan yang dikelola oleh Lembaga Keuangan Publik Islam. Di antara sistem keuangan Islam ada yang bersifat wajib (harus dilaksanakan) seperti zakat ada pula yang bersifat anjuran se- perti infak, sedekah, dan wakaf. Beberapa sistem keuangan Islam tersebut dewasa ini tengah digalakkan masyarakat muslim di berbagai belahan dunia. Tetapi Indonesia sebagai negara berpenduduk muslim terbesar, untuk pendistribusian zakat, infak, sedekah 
dan wakaf belum terlaksana sesuai yang diharapkan. Padahal Indonesia telah memiliki Undang-undang (UU) soal zakat. (Republika, 2003)

Selain itu, menurut hasil penelitian $\mathrm{Pu}-$ sat Bahasa dan Budaya UIN Syarif Hidayatullah dan Ford Foundation, potensi dana ZIS (Zakat, Infak, Sedekah) dan wakaf umat Islam Indonesia yang dapat dimanfaatkan untuk kesejahteraan masyarakat mencapai Rp 19,3 triliun, dalam bentuk barang Rp 5,1 triliun dan uang Rp 14,2 triliun. Jumlah dana sebesar itu, sepertiganya masih berasal dari zakat fitrah ( $\operatorname{Rp} 6,2$ triliun) dan sisanya zakat harta Rp 13,1 triliun. (Azra, 2003).

Sedangkan berdasar laporan perkembangan Penerimaan Dana Zakat, Infak, Shadakah, dan Wakaf (ZIS-W) Lembaga ZIS Dompet Dhuafa tahun 1993-2006 dan laporan Perkembangan Penerimaan Dana Zakat, Infak, dan Shadakah (ZIS) Lembaga Rumah Zakat Indonesia tahun 2004-2007 tampak dalam tabel 1.

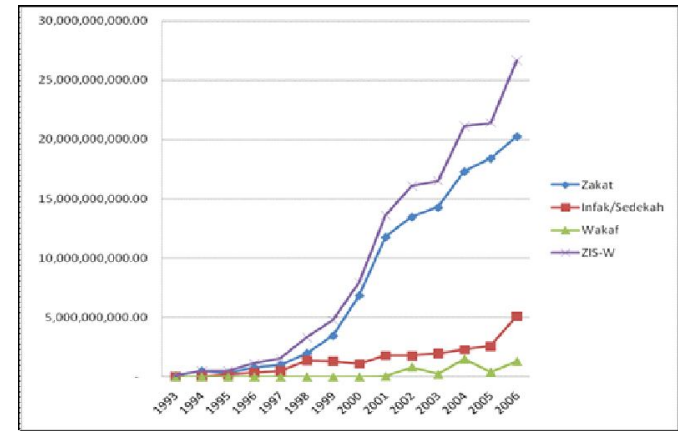

Gambar 1. Perkembangan Penerimaan Dana Zakat, Infak, Shadakah, dan Wakaf (ZIS-W) Lembaga ZIS Dompet Dhuafa

Dari kondisitersebut menunjukkan bahwa sistemkeuangan Islam dalam hal ini pengelolaan dana publik oleh Lembaga Keuangan Publik Islam yang di dalamnya ada Filantropi Islam secara umum terdiri dari institusi zakat, infak dan sedekah (ZIS) dan wakaf, belum mampu secara optimal berperan sebagai sumber dana untuk meningkatkan kesejahteraan masyarakat Indonesia, padahal

Tabel 1. Penerimaan Dana Zakat, Infak, Shadakah, dan Wakaf (ZIS-W) Lembaga ZIS Dompet Dhuafa

\begin{tabular}{|c|c|c|c|c|c|}
\hline Tahun & Zakat & Infak/Sedekah & Wakaf & ZIS-W & $\begin{array}{c}\text { Peningka } \\
\text { an }(\%)\end{array}$ \\
\hline 1993 & $87,868,209.00$ & - & - & $87,868,209.00$ & - \\
\hline 1994 & $506,110,483.00$ & - & - & $506,110,483.00$ & 475.99 \\
\hline 1995 & $291,399,230.00$ & $205,236,328.00$ & - & $496,635,558.00$ & -1.87 \\
\hline 1996 & $787,851,134.00$ & $353,948,216.00$ & - & $1,141,799,350.00$ & 129.91 \\
\hline 1997 & $1,018,933,644.00$ & $522,783,150.00$ & - & $1,541,716,794.00$ & 35.03 \\
\hline 1998 & $1,977,504,526.00$ & $1,361,059,987.00$ & - & $3,338,564,513.00$ & 116.55 \\
\hline 1999 & $3,442,751,636.00$ & $1,328,313,124.00$ & - & $4,771,064,760.00$ & 42.91 \\
\hline 2000 & $6,845,403,445.00$ & $1,106,144,193.00$ & - & $7,951,547,638.00$ & 66.66 \\
\hline 2001 & $11,773,058,922.00$ & $1,792,133,856.00$ & $50,610,000.00$ & $13,615,802,778.00$ & 71.23 \\
\hline 2002 & $13,474,288,999.00$ & $1,783,379,208.00$ & $822,451,600.00$ & $16,080,119,807.00$ & 18.10 \\
\hline 2003 & $14,280,869,804.00$ & $1,973,180,757.00$ & $229,713,000.00$ & $16,483,763,561.00$ & 2.51 \\
\hline 2004 & $17,308,550,429.13$ & $2,312,964,039.00$ & $1,502,420,652.00$ & $21,123,935,120.13$ & 28.15 \\
\hline 2005 & $18,412,806,845.00$ & $2,585,630,593.00$ & $406,662,500.00$ & $21,405,099,938.00$ & 1.33 \\
\hline 2006 & $20,255,041,469.00$ & $5,119,961,494.00$ & $1,313,559,280.00$ & $26,688,562,243.00$ & 24.68 \\
\hline
\end{tabular}

Sumber: Laporan Keuangan Dompet Dhuafa 
Optimalisasi Peran Wakaf dalam Pemberdayaan Usaha Mikro... (Sri Budi Cantika Yuli)

potensi dana ZIS dan wakaf sangat memungkinkan pelaksanaannya (Yulianti, 2008)

Sistem kesejahteraan sosial yang berakar dalam tradisi Islam (the Islamic welfare effort) merupakan bagian dari agenda yang ikut mewarnai interaksi antara Islam dan negara di Indonesia. Proses akomodasi negara terhadap sistem kesejahteraan sosial Islam mulai menguat pada akhir pemerintahan Orde Baru dengan pemberlakuan UU No. 38/1999 tentang pengelolaan zakat. Undang-undang ini menjadi dasar hukum yang menempatkan sistem kesejahteraan sosial Islam sebagai bagian penting darikebijakan dan sistem kesejahteraan sosial di Indonesia.

Gerakan muslimIndonesiauntuk memasukkan sistem kesejahteraan sosial Islam ke dalam sistem kesejahteraan nasional memiliki ciri khas dibandingkan dengan negaranegara muslim lain. Jika di negara-negara se- perti Pakistan, Sudan, Saudi Arabia dan Malaysia imajinasi tentang sistem ekonomi Islam sangat berpengaruh, maka gejala serupa tidak dijumpai di Indonesia. Alih-alih ekonomi Islam, cita-cita menerapkan Islam sebagai ideologi negara merupakan dasar untuk menempatkan pengelolaan dana zakat di bawah tanggung jawab inheren negara. Tidak heran jika di Indonesia sistem kesejahteraan sosial Islam, khususnya berkaitan dengan zakat, kerap kali menjadi satu isu sentral dalam ketegangan politik antara Islam dan negara (Yulianti, 2008).

Berdasar hasil penelitian PBB UIN dan the Ford Foundation (2003) ditemukan beberapa fakta yang menarik. Di antaranya, bahwa masyarakat muslim Indonesia memiliki tingkat kedermawanan yang tinggi dan dilandasi oleh motivasi spiritual. Sedangkan motivasi sosialnya masih rendah. Dari hasil studi

Tabel 2. Penerimaan Dana Zakat, Infak, Shadakah (ZIS) Lembaga Rumah Zakat Indonesia

\begin{tabular}{crrrc}
\hline Tahun & \multicolumn{1}{c}{ Zakat } & \multicolumn{1}{c}{ Infak/Sedekah } & \multicolumn{1}{c}{ ZIS } & Peningkatan $(\%)$ \\
\hline 2004 & $3,226,837,816.00$ & $515,420,977.00$ & $3,742,258,793.00$ & \\
2005 & $5,171,371,253.00$ & $864,830,597.00$ & $6,036,201,850.00$ & 61.30 \\
2006 & $8,216,443,928.00$ & $2,192,749,091.00$ & $10,409,193,019.00$ & 72.45 \\
2007 & $14,565,276,604.00$ & $6,827,071,947.00$ & $21,392,348,551.00$ & 105.51 \\
\hline
\end{tabular}

Sumber: Laporan Keuangan Rumah Zakat Indonesia

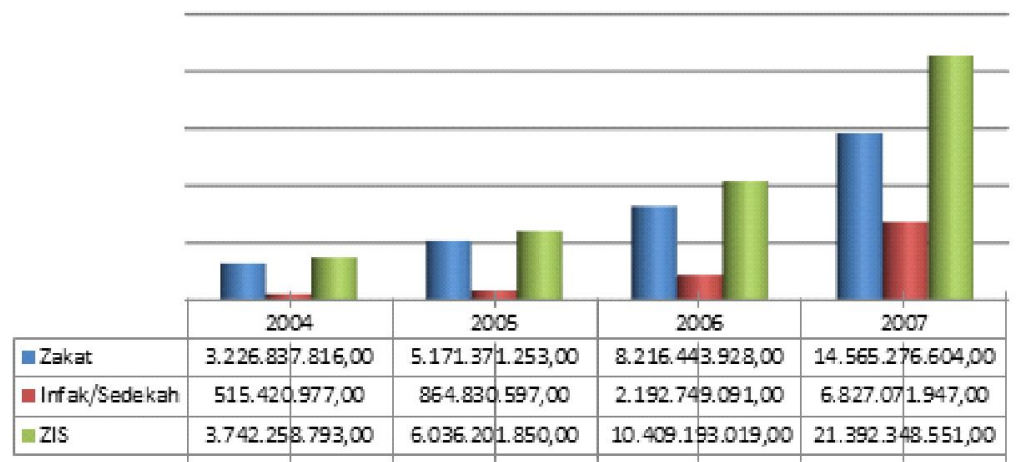

Gambar 2. Perkembangan Penerimaan Dana Zakat, Infak, dan Shadakah (ZIS)

Lembaga Rumah Zakat Indonesia 
kasus ini secara umum ditemukan bahwa otoritas agama masih sangat kuat melegitimasi wacana dan praktik pembayaran ZIS dan wakaf. Artinya masyarakat muslim di Indonesia sangat kuat dipengaruhi motif dan tujuan keagamaan yang dipahami dalam kerangka ketertundukan kepada doktrindoktrin keagamaan menurut tafsir klasik dalam ajaran berderma. Yaitu, berderma adalah ibadah dan cara mendekatkan diri kepada Allah swt melalui aktivitas-aktivitas bantuan karitatif kepada orang-orang miskin. Salah satu akar persoalannya ada pada formalisme zakat.

Artinya, zakat hanya dianggap sebagai kewajiban normatif, tanpa memperhatikan efeknya bagi pemberdayaan ekonomi umat. Akibatnya, semangat keadilan ekonomi dalam implementasi zakat menjadi hilang. Orientasi zakat tidak diarahkan pada pemberdayaan ekonomi masyarakat, tapi lebih karena ia merupakankewajiban dariTuhan. Bahkan, tidak sedikit muzakki yang mengeluarkan zakat disertai maksud untuk menyucikan harta atau supaya hartanya bertambah (berkah). Ini artinya, muzakki membayarkan zakat untuk kepentingan subyektivitasnya sendiri. Memang tidak salah, tapi secara tidak langsung, substansi dari perintah zakat serta efeknya bagi perekonomian masyarakat menjadi terabaikan.

Meskipun demikian terdapat suatu persepsi yang positif mengenai konsep keadilan sosial untuk mewujudkan kesejahteraan, namun secara umum paradigma keadilan sosial ini belum terintegrasi ke dalam konsep maupun praktik keagamaan dalam pembayaran ZIS dan wakaf di Indonesia. Yang perlu dilakukan adalah proses sosialisasi bahwa motivasi sosial semestinya lebih ditekankan dengan berlandaskan pada motivasi spiritual. Sementara mobilisasi dana ZIS dan wakaf
melaluiLembaga Keuangan Publik Islamatau organisasi ZIS terbentur dengan fakta bahwa masyarakat masihmenjunjung tinggi prinsip secrecy (kerahasiaan) dalam menyumbang, dan juga masih meragukan trust dari Lembaga Keuangan Publik Islam atau organisasi ZIS yang ada. Sedangkan, distribusi ZIS masih berorientasi pada aspek karitas atau sosial yang tidak bisa dikembangkan untuk kegiatan produktif dalam rangka pemberdayaan ekonomi masyarakat. Dengan kata lain, distribusi dana di Lembaga Keuangan Publik Islam untuk tujuan mewujudkan kesejahteraan masyarakat belum berperan secara optimal atau masih sangat lemah.

Model pendistribusian dana yang tidak menyertakan pemetaan ekonomi dan sosial juga menjadi cermin hilangnya spirit keadilan sosial ekonomi dalam zakat. Tidak sedikit muzakkiyang langsung memberikan zakat kepada faqir dan miskin tanpa memperhatikan apakah dana zakat tersebut mampu meningkatkan level kesejahteraan mereka atau tidak. Muzakki mungkin hanya berpikir tentang hukum, bahwa cukup baginya mengeluarkan zakat, sehingga kewajibannya sebagai muslim gugur. Di sinilah pentingnya amil dalam proses penyaluran zakat. Lembaga amil yang profesional sangat diperlukan agar proses pengumpulan dana (fundraising) serta pendistribusiannya dapat dilakukan secara efektif dan efisien. Salah satu membuatnya efektif dan efisien adalah dengan melakukan pemetaan sosial dan ekonomi. Susahnya, kadang-kadang menganggap amil hanya sekedar sebagai pos pengumpul zakat, tanpa tuntutan kerja optimal untuk usaha fundraising dan pola pendistribusian dana yang profesional.

Berkaitan dengan penguatan posisi amil ini, peningkatan profesionalisme lembaga-lembaga zakat adalah factor kunci. 
Profesionalisme ini meliputi upaya proaktif dalam fundraising dengan dua tujuan: meningkatkan pendapatan dana zakat dan meningkatkan jumlah orang sadar zakat. Termasuk profesionalisme lembaga zakat adalah mengoptimalkan pengelolaan dana zakat untuk pemberdayaan ekonomi dan peningkatan sektor riil. Karena itu, lembaga zakat perlu memiliki pemetaan sosial ekonomi yang baik, sehinga dana zakat tepat sasaran. Selain itu, model penyaluran dana zakat yang produktif harus lebih menjadi orientasi lembaga-lembaga zakat, daripada pola-pola distribusi dana konsumtif.

Dengan memperhatikan hal-hal tersebut di atas, zakat akan lebih bermanfaat bagi peningkatan kesejahteraan dan produktivitas masyarakat luas. Sudah saatnya pengelolaan dana zakat mengikuti misi profetik yang diemban Nabi, yaitu misi keadilan distribusi ekonomi dan meminimalkan konsentrasi harta hanya pada kelompok elit tertentu. Barangkalinegara masih belum mampu membebaskan diri dari kungkungan monster-monster ekonomi global. Namun dengan ajaran $\mathrm{Mu}-$ hammad, umat Islam dapat mengilhami pemerintah di negeri ini bagaimana cara berdiri di atas kaki sendiri dan melepaskan ekonomi Indonesia dari neoimperialisme negaranegara kapitalis. Salah satunya melalui manajemen zakat professional agar tercapai kesejahteraan masyarakat (Muhtada, 2007)

Sehubungan dengan hal tersebut, apabila dicari dalam literatur ekonomi, ternyata terminologi "kesejahteraan" memiliki banyak pengertian. Definisi "kesejahteraan" dalam sistem ekonomi kapitalis-konvensional merupakan konsep materialis murni yang menafikan keterkaitan ruhaniah. Konsep "kesejahteraan" yang memasukkan tujuan kemanusiaan dan keruhaniaan, tentu akan berakibat pada keharusan mendiskusikan secara ilmu ekonomi apa hakekat tujuan kesejahteraan tersebut dan bagaimana merealisasikannya. Tujuan-tujuan konsep kesejahteraan dalamkedua visi tersebut tidak hanya mencakup soal kesejahteraan ekonomi dalam arti materi semata, tetapi juga mencakup permasalahan persaudaraan manusia dan keadilan sosial-ekonomi, kesucian kehidupan, kehormatan individu, kehormatan harta, kedamaian jiwa dan kebahagiaan, serta keharmonisan kehidupan keluarga dan masyarakat.

Konsep kesejahteraan lahir bathin dapat dikatakan telah direalisasikan apabila unsur-unsur berikut telah terpenuhi, yaitu kebutuhan dasar bagi semua masyarakat terpenuhi, tingkat perbedaan sosial-ekonomi tidak terlalu mencolok, full employment (tidak adanya pengangguran usia produktif), keadilan dalam distribusi pendapatan dan kekayaan, stabilitas ekonomi dicapai tanpa beban hutang luar negeri yang berat, tingkat inflasi tidak tinggi, penyusutan sumber daya ekonomi yang tidak dapat diperbaharui tidak tinggi, dan kerusakan ekosistem yang dapat membahayakan kehidupan tidak terjadi.

Di samping hal-hal di atas, harus terpenuhi pula hal-hal sebagai berikut, yakni telah terwujudnya tingkat solidaritas keluarga dan sosial yang tinggi terhadap tanggung jawab bersama antara masyarakat dan pemerintah terhadap anak-anak, usia lanjut, orang sakit, orang-orang lemah, fakir miskin, keluarga bermasalah, janda-janda, penanggulangan kenakalan remaja, kriminalitas, dan kekacauan sosial serta pertikaian menyangkut SARA.

Untuk mencapai konsep kesejahteraan tersebut, setiap orang baik sebagai anggota masyarakat atau dunia usaha, maupun sebagai bagian dari organisasi pemerintahan diharuskan mengorbankan kepentingan pribadi demi memenuhi kemaslahatan sosial di lingkungan keluarga, dalam dunia usaha, hi- 
dup bermasyarakat, atau di dalam bidang pemerintahan. Selama maksimalisasi kekayaan dan konsumsiadalah satu-satunya tujuan, maka pengorbanan tidak akan ada artinya.

Meski berpeluang memainkan peran lebih besar di masa depan, namun secara umum kita belum benar-benar yakin akan kemampuan Lembaga Keuangan Publik Islam dalam merespon problematika sosial secara efektif karena kapasitas yang masih terbatas dibandingkan dengan problematika sosial yang maha kompleks. Dari sekian lembaga, ditemukan sejumlah hal yang menjadi kelemahan mendasar seperti rendahnya kualitas sumberdaya manusia dan lemahnya kapasitas organisasi dan manajerial. Belum melembaganya mekanisme pertanggungjawaban publik yang standar juga menjadi fenomena umum Lembaga Keuangan Publik Islam.

Keterbatasan iniberdasar pada kenyataan bahwa Lembaga Keuangan Publik Islambelummemiliki tradisikelembagaan yang kuat. Kultur Lembaga Keuangan Publik Islam sebaliknya lebih mengandalkan relasi interpersonal dan kapasitas individual. Padahal substansi peran Lembaga Keuangan Publik Islam untuk pemberdayaan ekonomi masyarakat lebih berorientasi pada penguatan institusi dan sistem. Dalam konsep Lembaga Keuangan Publik Islam untuk kesejahteraan, sumberdaya yang dikumpulkan ditujukan untuk menopang kegiatan yang mengarah kepada perubahan sosial. Dan perubahan tersebut hanya dapat dilakukan dengan strategi pengorganisasian masyarakat, advokasi dan pendidikan publik yang baik. Karenanya kultur Lembaga Keuangan Publik Islam yang personal tidak dapat diandalkan untuk melakukan tugas-tugas tersebut.

Konstruk Lembaga Keuangan Publik Islam yang demikian itu terbentuk akibat kuatnya pengaruh doktrin. Dalam Islam, doktrin memberi ruang seluas-luasnya bagi kebebasan individual dalam mempraktikkan berderma. Sejak masa awal Islam, zakat, infak dan sedekah (ZIS) dibayarkan langsung oleh muzaki kepada mustahik, sebagian lainnya dihimpun oleh pengurus masjid dan tokoh agama. Pola berderma semacam ini relevan dengan struktur sosial ketika pola itu cukup kredibel di mata umat. Pasalnya, dalam Islam akuntabilitas personal mendapat resonansi sangat kuat dalam doktrin. Realitas ini mungkin dapat menjawab pertanyaan mengapa kedermawanan Islam tidak tampil dalam format kelembagaan yang kuat. Sehingga perlu dorespon Lembaga Keuangan Publik Islam yang kuat secara sistemik.

Lembaga Keuangan Publik Islam yang di dalamnya ada Filantropi Islam secara umum terdiridari institusi zakat, infak dan sedekah (ZIS) dan wakaf. Dalam ajaran Islam, ZIS mengandung pengertian yang sama dan acap digunakan secara bergantian, atau dapat dipertukarkan, untuk maksud yang sama, yaitu berderma. Dalam ayat 60 , surat at-Taubah, yang sering dirujuk sebagai ayat berderma, tidak mengintrodusir istilah zakat, tetapi shadaqah. Namun, pada tataran diskursus penggunaan istilah Zakat, Infak dan Sedekah mengandung makna yang spesifik dan berbeda. Zakat sering diartikan sebagai membelanjakan (mengeluarkan) harta yang sifatnya wajibdan salah satu rukun Islam serta berdasarkan perhitungan yang tertentu. Infak acap merujuk kepada pemberian yang bukan zakat, yang kadangkala jumlahnya lebih besar dari zakat. Biasanya dimaksudkan untuk kepentingan fii sabilillah, dalamarti sarana, misalnya, bantuan untuk masjid, madrasah, pondok Pesantren, rumah sakit. Pendek kata, bantuan yang dikeluarkan untuk lembaga keumatan umat tersebut masuk kategori infak. Sedangkan, sedekah biasanya 
Optimalisasi Peran Wakaf dalam Pemberdayaan Usaha Mikro... (Sri Budi Cantika Yuli)

derma yang kecil-kecil jumlahnya yang diserahkan kepada orang miskin, pengemis, pengamen dll. Berbeda dengan zakat, baik infak maupun sedekahkeduanya adalah sunnah.

Dalam konteks Indonesia, zakat pada awalnya acap dibayarkan langsung oleh $m u z$ zaki kepada mustahik, dan juga dihimpun melalui tokoh agama maupun masjid. Pola berderma semacam ini tradisional sifatnya, meskipun cukup kredibel di mata umat. Namun sejak abad ke 20, KH Ahmad Dahlan, perintis Muhammadiyah, mengusulkan dibentuknya lembaga amil zakat, yaitu lembaga perantara (intermediary institusion) yang menerima atau menggalang zakat dari para muzaki dan menyalurkan mustahik seperti ditunjukkan dalam surat at-Taubah: 60. Dengankatalain, sesungguhnya pengelolaanLembaga Keuangan Publik Islam melalui organisasi yang moderen belum lama dilakukan. Artinya Lembaga Keuangan Publik Islam maupun organisasi filantropi Islam adalah fenomena modern, meskipun praktek berderma telah berurat akar dalam setiap etnik dan budaya masyarakat Indonesia. Praktek berderma yang hidup tersebut umumnya diterapkan secara tercerai berai (decentrali$z e d$ ), tidak terkoordinir secara nasional,ada yang tidak transparan dan untuk maksud yang berbeda-beda serta umumnya kuat dimotivasi oleh ajaran agama.

Sementara itu, jika mereferensi kepada hadis Nabi yang otentik, maka terminologi wakaf berbeda halnya dengan zakat atau sedekah. Akan tetapi, wakaf dapat dikategorikan sebagai infak. Dengan kata lain, konsep infak mencakup wakaf. Terminologi wakaf sendiri tidak secara eksplisit disitir di dalam alQur'an. Wakaf lahir dari pandangan Nabi saw ketika merespon pertanyaan Umar bin Khattab yang bermaksud menginfakkan sebidang tanah di Khaibar. Nabi bersabda,
"Bila engkau suka kau tahan (pokoknya) tanah itu, danengkau sedekahkan hasilnya". Sejarah meriwayatkan bahwatanah wakaf Umar itu dipergunakan untuk fakir miskin, pemerdekaan budak, orang terlantar dll. Sebagian Ulama memandang syari' at wakaf pertama kali dilaksanakan oleh Umar bin Khattab. Artinya wakaf mengindikasikan pemanfaatan hasil tanahnya, namun kekekalannya tetap terpelihara.

Sebagai salah satu institusi filantropi Islam, wakaf di dunia Muslimtelah memainkan peran yang signifikan dalam pemberdayaan sosial ekonomi umat. Misalnya, di Mesir, Yordania, Saudi Arabia dan Bangladesh dengan manajemen yang profesional, maka manfaat wakaf telah dirasakan oleh pihak yang memerlukannya. Sebaliknya, di Indonesia wakaf belum mampu memainkan peran seperti beberapa negara Muslim yang disebut tadi. Secara spesifik, wakaf, sebagai satu institusi filantropi Islam telah dipraktekkan sejak abad ke-15, ketika komunitas Muslimkhususnya di Jawa mulai mendirikan masjid dan pesantren sebagai institusi pendidikan keagamaan. Menurut Ridwan, orientasi wakaf sebagai satu tindakan kemasyarakatan (sosial) harus diperkuat, karena trend umum di Indonesia wakaf diperuntukkan untuk tempat ibadah (75\%), sedangkan wakaf untuk tujuan kemasyarakatan sangat minim, termasuk juga wakaf untuk institusi pendidikan seperti pesantren, madrasah dan perguruan tinggi (universitas).

Secara umum, ada beberapa tantangan Lembaga Keuangan Publik Islamuntuk kesejahteraan di Indonesia. Pertama, organisasi-organisasi pengelola zakat (BAZIS dan LAZIS) belum menunjukkan akuntabilitas dan transparansi yang memadai. Kedua, rekonseptualisasi fikihLembaga Keuangan Publik Islam maupun filantropi yang modern, 
misalnya mengenai pemahaman konseptual asnaf delapan, cash wakaf (wakaf tunai) atau wakaf produktif. Selain itu, diandaikan adanya satu pendekatan "pembangunan" yang lebih menitikberatkan pada investasi di bidang infrastruktur untuk menuai keuntungan jangka panjang ketimbang sekedar mengatasi masalah-masalah jangka pendek.

\section{Optimalisasi Peran Wakaf dalam Pemberdayaan UMKM}

Untuk memenuhi kebutuhan kelompok Usaha Mikro Kecildan Menengah (UMKM) produktif, lembaga pengelola wakaf uang dapat melakukan pemberdayaan dengan memberikan bantuan modalinvestasi maupun modal kerja pada anggota pada khususnya yang sebagian besar merupakan anggota kelompok produktif. Peran lembaga nazhir wakaf lainnya dalam pemberdayaan Usaha Mikro Kecil dan Menengah (UMKM) antara lain memberikan pelatihan, konsultasi usaha, peningkatan keterampilan, maupun peningkatan kualitas produk. Untuk mengurangi beban pemerintah dan rakyat, model wakaf uang sangat tepat dalam bentuk melancarkan ketersumbatan fungsifinancial intermediary. Terjadinya arus lancar (cash flow) penyaluran dana ke seluruh anggota masyarakat termasuk kelompok usaha UMKM. Melalui wakaf uang akan terjadi proses distribusi manfaat bagi masyarakat secara lebih luas (Rozalinda, 2013).

Al-Jamal (2007) dalam hal ini menegaskan, peranan wakafdalam memenuhikebutuhan ekonomi masyarakat dapat dilihat dari beberapa segi, yakni 1) Melalui simpanan wakaf yang ditujukan untuk melayani proyek-proyek pembangunan, akan tercapai kekuatan finansial baru yang menyokong perekonomian negara. Aset-aset wakaf itu adalah kebutuhan financial yang tetap eksis dan selalu membantu ekonomi negara. 2) Membantu pendirian infrastruktur. 3) Memberikan kesempatan untuk mendapatkan pekerjaan dan mengurangi pengangguran. 4) Berpartisipasi dalam menambah gerakan bisnis di masyarakat. Oleh karena itu, harta wakaf bisa diekploitasi dalam skala besar sehingga bisa diberikan subsidi, penyediaan kesempatan kerja, dan penyediaan lembaga-lembaga pelatihan kewirausahaan

Masyita (2005) menyatakan bahwa dana wakaf uang dapat diinvestasikan dan disalurkan untuk memberdayakan masyarakat kecil melalui mikro finance dan pendampingan usaha. Bantuan keuangan mikro ini didampingi oleh sarjana pendamping yang akan memberikan konsultasi kepada penerima kredit mikro agar dapat pengetahuan cara berusaha dan berbisnis dengan baik. Dengan pemberian modal dan bantuan manajemen perlahan-lahan masyarakat miskin dapat terangkat derajatnya melalui usaha mikro yang pada akhirnya mampu hidup layak dan sejahtera. Perencanaan dan pengembangan program kredit mikro yang tepat akan memperkuat nilai-nilai kekeluargaan.

Kegiatan-kegiatan dalam rangka peningkatan kapasitas dan kualitas UMKM di bidang ekonomi dapat dilakukan. dengan menekankan pada 5 aspek, yaitu: Pertama, Pengembangan kapasitas dan karakter. Dalam programini dilakukan kegiatan-kegiatan pelatihan wirausaha secara komprehensif, mulai dari motivasi berusaha, manajemen usaha, dan hal lainnya seputar kewirausahaan untuk UMKM. Kedua, Konsultasi dan pendampingan. Setelah pelatihan, para wanita kemudian mendapatkan konsultasi dan pendampingan usaha untuk bisa menguatkan dan meng-upgrade kapasitas serta kualitas usahanya di masa depan.

Ketiga, Organisasi. Sebagaiindividu ataupun kelompok usaha, UMKM sangat mem- 
Optimalisasi Peran Wakaf dalam Pemberdayaan Usaha Mikro... (Sri Budi Cantika Yuli)

butuhkan penguatan di bidang organisasi bisnisnya. Di tahapanini diharapkan para wanita yang berwirausaha mampu menjalankan bisnisnya dengan aturan yang berlaku dan memiliki visi yang jelas. Keempat, PasarUMKM mendapatkan pengetahuan mengenai upaya membuka dan membangun pasar untuk produk-produk yang telah dimiliki. Kelima, Jejaring. Diharapkan UMKM dan kelompok usaha UMKM mampu menemukan, membuat, dan menguatkan jaringan sosial untuk usahanya.

Strategi pemberdayaan ekonomi bagi UMKM yang tidak memiliki kapasitas produktif, tidak mempunyai keahlian (skill) dan modal sehingga mereka belum memiliki usaha, dapat ditempuh melalui langkah-langkah sebagai berikut: Pertama, Pelatihan usaha bertujuan untuk memberikan wawasan yang luas tentang kewirausahaan secara aktual dan komprehensif sehingga mampu memunculkan motivasi dan spirit berwirausaha. $\mathrm{Ke}$ $d u a$, Pemagangan. Setelah memiliki pemahaman dan motivasi kewirausahaan, maka dibutuhkan keterampilan. Itu bisa diperoleh melalui kegiatan magang di dunia usaha yang akan diterjuninya. Ketiga, Penyusunan proposal. Menyusun proposal secara realistis berdasarkan pengalaman empiris perlu dimilikiuntuk mengindari penyimpangan sehingga bisa meminimalisir kerugian.

Keempat, Permodalan sangat penting untuk memulai dan mengembangkan usaha. Dalam hal ini harus dicari lembaga keuangan yang dapat meminjami uang dengan bunga/ bagi hasil seringan mungkin. Jangan sampai keuntungan yang diperoleh habis untuk membayar utang. Kelima, Pendampingan, berfungsi sebagai pengarah dalam melaksanakan kegiatan usahanya sehingga mampu menguasai dan mengembangkan usahanya dengan mantap. Keenam, Membangun jaringan bisnis.
Tahapan ini sangat berguna untuk memperluas pasar sehingga produk-produknya dapat dipasarkan ke daerah-daerah lain. Dengan jaringan ini akan melahirkan networking bisnis umat Islam yang tangguh.

Demikianlah langkah-langkah pemberdayaan ekonomi UMKM yang belum memiliki usaha permanen, benar-benar dimulai dari titik nol. Ini berbeda dengan model pemberdayaan ekonomi bagi UMKM yang telah memiliki kapasitas distributif, telah memiliki usaha. Strategi pemberdayaan ekonomi UMKM yang telah memiliki rintisan usaha, dilakukanmelalui langkah-langkah sebagai berikut: Pertama, Membantu akses permodalan, diawali dari pembimbingan penyusunan proposal yang memadai sehingga mampu meyakinkan pihak lembaga keuangan untuk mengucurkan dananya. Kedua, Menertibkan administrasi keuangan. Masalah administrasi adalah titik lemah para pelaku usaha kecildan menengah; tidak ada catatan transaksi jual-beli, campur aduk keuangan usaha dengan rumah tangga dan lain-lain. Harus ada bimbingan untuk menertibkan administrasi keuangan sehingga bisa diaudit sesuai dengan prinsip-prinsip akuntansi modern.

Ketiga, Memperbaiki manajemen usaha. Meski usahanya masih kecil, jumlah karyawan sedikit, dan jangkauan pemasaran masih lokal, namun harus dikelola dengan manajemen yang sehat. Keempat, Memperluas pemasaran. Pemasaran menjadi kendala yang serius bagi usaha kecil dan menengah dalam melempar produk-produknya ke masyarakat, karena tidak tersedia dana iklan. Oleh karena itu ethos kerja harus senantiasa dipompa, informasitentang peluang-peluang pasar baru harus disediakan, dan pengembangan jejaring sesama usaha kecil dan menengah. Kelima, Teknis produksi, maksudnya kualitas produk harus dijaga terus-menerus 
seirama dengan tuntutan pasar. Kualitas produk harus benar-benar dijaga meskipun sudah laku di pasar. Keenam, Teknologi, baik teknologi produksi maupun teknologi informasi harus dimanfaatkan secara optimal sehingga dapat menstimulasi peningkatan kualitas produksi.

Program pemberdayaan ekonomi UMKM sebagaimana dijelaskan di atas, tidak dilakukan dalam ruang sosial-ekonomipolitik yang hampa. Lembaga nazhir wakaf uang di samping menguasai langkah-langkah pemberdayaan ekonomi UMKM, juga dituntut kemampuannya dalam membaca realitas sosial budaya-ekonomi-politik yang melatari umat Islam. Untuk meningkatkan peran ekonomi UMKM sekaligus peningkatan status UMKM perlu tindakan strategis yakni: Pertama, Mengadakan tindakan yang positif yang memungkinkan UMKM memperoleh akses yang sama terhadap sumber daya, pekerjaan, pasar dan perdagangan. Untuk mencapai tujuan ini, perlu dilakukan pengembangan dan bantuan bagi UMKM agar mereka mampu berwiraswasta mengembangkan usaha kecil, memperoleh akses kredit dan modal. $\mathrm{Ke}$ $d u a$, Memberikan akses bisnis yang sama pada UMKM untuk memperoleh kesempatan pelatihan dan konseling terutama dalambidang pengembangan teknologi baru, mendesiminasikan informasi yang mereka butuhkan dan mengembangkan jaringan kerja serta membuka kesempatan kerja yang lebih luas minimal usaha-usaha tradisional UMKM.

Kelompok Filantropis berkeyakinan bahwa posisi dan situasi masyarakat yang miskin dan terbelakang itu dapat diubah lewat upaya kemanusiaan, tanpa mengubah kelembagaan dan struktur masyarakat. Upaya kemanusiaan secara evolutif akan meningkatkan kondisi sosial, ekonomi dan budaya masyarakat.
Wakaf uang adalah salah satu sumber alternatif dana untuk program penanggulangan kemiskinan. Dengan menggalang dana wakaf uang dari orang-orang yang mampu, yang mempunyai kesadaran dan kepedulian yang tinggi terhadap orang-orang yang kurang mampu, memberikan peluang kepada masyarakat untuk mendapatkan dan meningkatkan pendapatan. Wakaf yang terhimpun, dikelola secara produktif, kemudian keuntungannya disalurkan sebagai modal usaha kepada orang-orang yang kekurangan modal. Dari wakaf uang ini betapa banyak petani dan pedagang kecilyang mendapat tambahan modal usaha, betapa banyak orang hidup di bawah garis kemiskinan dapat merasakan manfaatnya, seperti menyantuni anak yatim, membantu biaya operasional sekolah, dan balai kesehatan pun dapat melayani orang miskin dari hasil wakaf. (Masyita, 2005)

Wakaf merupakan instrumen finansial Islam yang memiliki keterkaitan langsung secara fungsional dengan upaya pemecahan masalah-masalah sosial dan ekonomi, seperti pemberdayaan ekonomi UMKM, pengentasan kemiskinan, dan peningkatan kualitas sumber daya manusia. Dengan demikian wakaf sesungguhnya memiliki peranan yang cukup besar dalam mewujudkan tata sosial yang berkeadilan. Dalamjangkauan yang lebih luas, kehadiran wakaf uang dapat dirasakan manfaatnya untuk meningkatkan taraf hidup masyarakat di bidang ekonomi, terutama sekali jika wakaf dikelola dengan manajemen yang rapi, teratur dan profesional disertai kualitas para pengelolanya.

Dalam mengalokasikan investasi wakaf uang, lembaga pengelola wakaf uang dapat memilih kelompok usaha misalnya kelompok usaha UMKM yang berhimpun dalam suatu usaha, ataupun wilayah/kawasan yang masyarakatnya memiliki usaha yang sama. 
Optimalisasi Peran Wakaf dalam Pemberdayaan Usaha Mikro... (Sri Budi Cantika Yuli)

Misalnya, penyaluran wakaf uang untuk usaha perkebunan, peternakan dan jenis usaha produktif lainnya. Pengaruh pengelolaan wakaf uang melalui pemberian modal kerja kepada mitra binaannya telah terbukti memberikan kesempatan kepada masyarakat untuk membuka usaha, ataupun membantu pengembangan usaha produktif masyarakat yang kekurangan modal.

Model pengembangan dan pemberdayaan ekonomi UMKM sebagai upaya pencerahan sosial ekonomi kelompok usaha UMKM ini dalam pelaksanaanya harus dilakukan sesuai dengan kondisi obyektif dan karakteristik sosio-kulturaldan ekonomi yang akan ditransformasikan. Dengan pembacaan atas realitas sosial yang akurat, maka wakaf uang sebagai instrumen pemberdayaan ekonomi umat akan tepat sasaran sehingga prinsip ekonomi Islamuntuk membangun keseimbangan ekonomi umat benar-benar dapat terealisasikan.

Menurut Soetrisno (2013), dana wakaf bisa memberdayakan usaha kecil yang masih dominan di negeri ini $(99,88 \%)$. Dana wakaf yang terkumpul dapat disalurkan kepada masyarakat termasuk kelompok pengusaha UMKM dengan sistembagihasil. Keuntunganinvestasi wakaf uang dipakai untuk program pemberdayaan (enpowerment) rakyat miskin sehingga modal dapat digunakan secara berkelanjutan, bahkan kalau memungkinkan modal itu bisa diputar ke orang lain yang juga membutuhkan, baik dalam rangka memperkuat kapasitas distributif ataupun sebagai modal awal untuk memulai sebuah usaha (kapasitas produktif).

Untuk mengukur pengaruh yang dimunculkan dari pengelolaan wakaf uang dapat dilihat dari indikator-indikator berupa pergerakan sektor riil dan pemberdayaan ekonomi masyarakat. Menurut MA Mannan, salah satu indikator efektivitas wakaf uang adalah income redistribution (redistribusi pendapatan). Pengeluaran dana-dana yang diperoleh dari hasil pengelolaan wakaf berperan penting pada setiap redistribusi pendapatan secara vertikal. Pengeluaran danadana wakaf harus dikoordinasikan sehingga efek redistribusi pendapatan dapat berpihak pada golongan miskin, yakni dengan penyediaan jasa dan prasarana penting bagiorang miskin, misalnya sarana pendidikan. Berdasarkan apa yang telah dibuktikan MA Mannan di SIBL, dengan pengelolaan wakaf yang efektif, redistribusi pendapatan horizontal telah terjadi secara siginifikan dari satu kelompok pendapatan ke kelompok pendapatan yang lain (Mannan, 1999) Seperti halnya zakat, Menurut Ahmed (2004), wakaf dapat memberikan pengaruh terhadap kegiatan ekonomi secara mikro, mempunyai kontribusipositif dalam rangka meningkatkan kesejahteraan umat.

Manfaat yang dirasakan masyarakat melalui investasi dana wakaf ini cukup besar. Masyarakat mendapatkan modal pembiayaan dan bagi hasilnya. Mereka pun mendapat binaan baik dalam bentuk bisnis, maupun dalam bentuk mental spiritual dari kelompok binaanya untuk melakukan usaha dan dengan cara yang halal. Misalnya yang telah dilakukan Tabung Wakaf Indonesia (TWI) melalui LPEU Insan Kamil mitra binaan TWI yang ada di Palembang, Masyarakat Mandiri yang ada di Jakarta dan Bogor, dan Kampung Ternak mendapat kucuran dana wakaf uantuk mengembangkan usaha mereka. Yang tidak kalah pentingnya lagi adalah pendidikan mental dan moral masyarakat. Dimana masyarakat dalam kelompok usaha dibina untuk mempunyai jiwa entrepreneurship sehingga mereka yang sebelumnya mencari kehidupan dari cara yang tidak halal, dapat 
meninggalkan kebiasaan tersebut dengan mencari usaha yang halal. Begitu juga, masyarakat binaan diberikan semacam dorongan spiritual berupa dorongan untuk bekerja pada sektor-sektor yang halal. Di samping itu, mereka juga dimotivasi untuk menyisihkan sebagai rizkinya untuk diwakafkan dan motivasi lainnya yang mengajak masyarakat kepada kebaikan.

Program investasi wakaf uang ke sektor ril seperti ini merupakan bentuk pengejawantahan program pengentasan kemiskinan. Di samping itu, sistem penjaringan kelompok usaha UMKM, tentu akan lebih memudahkan melakukan monitoring usaha sehingga risiko usaha lebih dapat diminimalisir. Di samping itu sistem penjaringan kelompok masyarakat seperti ini, manfaat wakaf tentu juga dapat dinikmati oleh banyak orang. Betapa banyak kelompok usaha UMKM yang dapat diberikan bantuan modal dan betapa banyak pula orang miskin yang dapat menikmati hasil usaha dari investasi wakaf uang. Wakaf uang seperti yang diinvestasikan, terbukti memberi kesempatan pada masyarakat untuk pengembangan usaha dan pemberdayaan ekonomi. Ini berarti investasi wakaf uang ke sektor ril berpengaruh positif pada peningkatan kesejahteraan hidup masyarakat sekaligus memberikan kesadaran akan makna wakaf itu sendiri.

Investasi wakaf uang untuk sektor riil mencoba mencontoh apa yang yang telah dilakukan di Mesir, negara yang terhitung sukses dalam pengelolaan wakafnya, di mana Mesir sejak disahkannya Undang-undang Nomor 152 Tahun 1957 mengembangkan wakaf tanah pertanian untuk meningkatkan perekonomian umat (Basa, 2007). Kementerian Perwakafan (Wizarah al Awqaf) di negeri ini membangun tanah-tanah kosong yang dikelola secara produktif dengan men- dirikan lembaga-lembaga perekonomian, ataupun dalam bentuk pembelian saham di perusahaan-perusahaan. Hasil pengelolaan wakaf ini disalurkan untuk membantu kehidupan masyarakat miskin, anak yatim piatu, pedagang kecil (Al-Jamal, 2007)

Menurut Zarqa (2008), Professor pada Center for Research in Islamic Economics Universitas King Abdul Aziz, wakaf sebetulnya telah dikenal dalam masyarakat sejak masaklasik. Islammengakui tradisi yang mulia ini dan menempatkannya sebagai ajaran agama yang abadi, sehingga wakaf tumbuh subur dalam masyarakat Islam sepanjang sejarah. Lalu menepatkannya sebagai pelayanan sosial yang penting, khususnya dalampembangunan masjid, sekolah, rumah sakit, sumber air minum, dan dukungan untuk orang miskin.

Dalam sejarahnya, substansi wakafuang sebenarnya telah lama muncul. Bahkan, dalam kajian fiqih klasik seiring dengan munculnya ide revitalisasi fiqih mu' amalah dalam perspektif maqashid syariah yang bermuara pada maslahah al-mursalah termasuk upaya mewujudkankesejahteraan sosial melalui keadilan distribusi pendapatan dan kekayaan.

Dengan demikian tidak diragukan lagi bahwa wakaf memberikan banyak manfaat bagi kehidupan masyarakat baik sosial maupun ekonomi. Dariperspektif sosial, wakaf dapat digunakan sebagai sarana untuk mengurangi kemiskinan, kontrol dan keharmonisan kehidupan sosial, serta meningkatkan perpaduan sosial. Begitu mengesankannya wakaf, dapat menghindarijarak kelas sosial antara orang kaya dan miskin karena orang yang mampu secara sukarela membagikan kekayaan mereka pada orang yang kurang mampu. Dana yang disalurkan ke lembaga pengelola wakaf, dikelola secara produktif, 
yang kemudian surplus pengelolaannya disalurkan kepada orang-orang yang kekurangan modal usaha. Dengan demikian, produktivitas wakaf akan memicu terciptanya keadilan sosial yang dengan segera dapat menciptakan dukungan bagi kemakmuran masyarakat. Di sini terlihat adanya bentuk distribusi pendapatan dari pihak yang mempunyai pendapatan yang lebih kepada pihak yang berpendapatan rendah. Dari efek distribusi pendapatan ini jelas akan membuat pemerataan pendapatan secara adil bila wakaf uang inibenar-benar dikelola secara efektif (Donna dan Mahmudi, 2007).

Berdasarkan laporan yang ditulis Maurice Allais, peraih Nobel tahun 1988 dalam bidang ekonomi (dalam Masyita, 2005), dari sebanyak US\$ $420 \mathrm{M}$ uang yang beredar di dunia per hari, hanya sebesar US\$12,4 M $(2,95 \%)$ saja yang digunakan untuk keperluan transaksi. Sisanya, untuk keperluan spekulasi dan judi, sedangkan situasi yang diharapkan adalah bila terjadi keseimbangan antara sektor moneter dan sektor riil. Sektor moneter semestinya tidak berjalan sendirimeninggalkan sektor ril. Oleh karena itu, sangat tepat bila penyaluran dana dalam bentuk pembiayaan produktif ke sektor riil dimobilisasi. Salah satu bentuknya adalah dengan memberikan kredit mikro melalui mekanisme Kontrak Investasi Kolektif(KIK) semacam reksadana syariah yang dihimpun dari sertifikat wakaf uang, kepada UMKM yang berkecimpung pada usaha menengah dan kecil agar memiliki peluang usaha. Pemberian skim kredit mikro tersebut cukup mendidik. Lebih baik memberikan kail kepada rakyat daripada memberikan ikan. Hal itu diharapkan mampu menumbuhkankemandirian UMKM.

Sejalan dengan ini, menurut Habib Ahmed dalam Role of Zakat and Awqaf in Poverty Alleviation, dana wakaf juga da- pat diberikan sebagai pinjaman kepada masyarakat yang kurang mampu. Seperti halnya zakat, wakaf dapat digunakan untuk pembiayaan sektor mikro kepada orang miskin. Keuntungan dari wakaf pun di samping sedekah dapat juga digunakan untuk pembiayaaan produktif sektor mikro. Wakaf uang yang dinvestasikan dalam format mudharabah dapat membangkitkan pendapatan dari investasi yang digunakan untuk tujuan sukarela. Porsi bagi hasil untuk fund manager setelah dikurang biaya operasional dapat disalurkan untuk kebutuhan konsumtif dalam menunjang kesejahteraan kaum dhuafa melalui wasiat wakif ataupun tanpa wasiatnya (Ahmed, 2004).

Investasi mudhârabah merupakan salah satu alternatif yang ditawarkan oleh produk keuangan syari' ah guna mengembangkan harta wakaf. Salah satu contoh yang dapat dilakukan oleh pengelola wakaf dengan sistem ini adalah membangkitkan sektor usaha kecil dan menengah dengan memberikan modal usaha kepada petani, pedagang kecil, dan menengah (UKM). Dalamhal ini pengelola wakaf uang (nazhir) berperan sebagai shahibul mal yang menyediakan modal 100\% dari usaha/proyek dengan sistem bagi hasil. Pengusaha seperti pengusaha UMKM adalah sebagai mudharib yang memutarkan dana wakaf tersebut. Hasil keuntungan yang diperoleh dibagi bersama antara pengusaha dengan shahibul mal (nazhir wakaf).

Wakaf dapat mengatasi stagnasi (kelesuan) ekonomi. Wakafmemilikiperanefektif dalam menekan unsur-unsur produktivitas yang terabaikan, memiliki kemampuan maksimal dalam memerangi pengangguran, serta punya pengaruh jelas dalam pengalokasian pendapatan dan kekayaan. Usaha wakaf dalam pembangunan dan pemusatan eksperi- 
Ekonomika-Bisnis Vol. 6 No.1 Bulan Januari Tahun 2015. Hal 1-16

men di bidang tersebut secara terus menerus membuat lembaga-lembaga wakaf berkembang menjadi suatu sistem yang bisa menghadapi krisis. Dengan demikian wakaf merupakan payung pelindung dari fluktuasi dan badai ekonomi (Al Jamal, 2007).

Wakaf uang menawarkan peluang untuk membantu kelompok usaha UMKM dalam meningkatkan pendapatan dari bagi hasil yang diperolehnya. Lebih lanjutnya tentunya pendapatan ini memberi dampak positif bagi perubahan kehidupan ekonomi keluarga. Apalagi investasi dana wakaf yang disalurkan dalam bentuk dana bergulir yang dijadikan modal usaha bagi masyarakat lainnya secara berkelanjutan. Betapa banyak UMKM yang dapat diberdayakan kehidupan ekonominya dan betapa banyak masyarakat yang dapat menikmati manfaat investasi wakaf uang, sungguh suatu instrumen keuangan Islam yang sangat potensial.

Lembaga pengelola wakaf uang merupakan wadah yang paling tepat bagi kelompok UMKM pelaku usaha yang biasa disebut kelompok produktif dalam meningkatkan usahanya. Lembaga ini mempunyai potensi besar dalam pemberdayaan UMKM, yang kebanyakan adalah pelaku usaha mikro kecil(UMK), yang diketahui mempunyai kelemahan dalam mengakses sumber-sumber produktif seperti modal, teknologi, pasar, informasi. Dengan berkelompok mereka dapat secara bersama-sama dipermudah memperoleh modal usaha.

Dengan kata lain lembaga pengelola wakaf uang (nazhir) dapat berperan strategis memberdayakan UMKM, dan sebaliknya dengan koperasi UMKM dapat membuktikan kompetensi dan kelebihannya, sebagaimana ditunjukkan oleh keberhasilan beberapa koperasi dan UMKM.

\section{Penutup}

Usaha Mikro, Kecil dan Menengah (UMKM) dapat menjadi kekuatan di dalam pengentasan kemiskinan, penciptaan lapangan kerja dan menjadi kekuatan di dalam meningkatkan pendapatan keluarga.

Wakaf uang berperan strategis memberdayakan Usaha Mikro, Kecil dan Menengah (UMKM). Wakaf uang menawarkan peluang untuk membantu kelompok usaha dalam meningkatkan pendapatan dari bagi hasil yang diperolehnya. Lebih lanjutnya tentunya pendapatan ini memberi dampak positif bagi perubahan kehidupan ekonomi keluarga. Apalagi investasi dana wakaf yang disalurkan diberikan dalam bentuk dana bergulir yang dijadikan modal usaha bagi masyarakat lainnya secara berkelanjutan.

Dana wakaf uang dapat diinvestasikan dan disalurkan untuk memberdayakan masyarakat kecil melaluimicro finance dan pendampingan usaha. Bantuan keuangan mikro ini didampingi oleh tenaga pendamping yang akan memberikan konsultasi kepada penerima kredit mikro agar dapat pengetahuan cara berusaha dan berbisnis dengan baik. Dengan pemberian modal dan bantuan manajemen perlahan-lahan masyarakat miskin dapat terangkat derajatnya melalui usaha mikro yang pada akhirnya mampu hidup layak dan sejahtera.

\section{DAFTAR PUSTAKA}

Al-Jamal, Ahmad Muhammad Abdul Azhim. 2007. Daur Nizâmal-Waqfal-Islâmî fi al-Tanmiyah al-Iqtishâdiyah alMu'âshirah. Dâr al-Salâm. Kairo.

Azra, Azyumardi. 2003. Diskursus Filantropi Islam dan Civil Society, dalam Berderma Untuk Semua: 
Optimalisasi Peran Wakaf dalam Pemberdayaan Usaha Mikro... (Sri Budi Cantika Yuli)

Wacana dan Praktik Filantropi Islam, Jakarta: PBB, Ford Foundation, dan teraju, hlm. xxiii. Lihat juga hasil penelitianPBBUIN Syarif Hidayatullah dan Ford Foundation, Philantropi Untuk Keadilan Sosial: Studi Kasus Masyarakat Muslim Indonesia.

Ahmed, Habib. 2004. Role of Zakat and Awqaf in Poverty Alleviation. Jedah: Islamic Research and Training Institution, Islamic Development Bank.

Basa, Muhammad Qadr. 2009. Qanûn alAdl wa al-Inshaf fi al-Qadha' ala Musykilât al-Auqâf, (Kairo: Dâr asSalâm, 2006), Lihat juga Murat Cizakca, A History of Philanthropic Foundations: the Islamic World From the Seventh Century to the Present, www.mcizakca. com/publications.htm.

Donna, Duddy Roesmara dan Mahmudi. 2007. The Dynamic Optimization of Cash Waqf Management:an Optimal Control Theory Approach, http:// psekp.ugm.ac.id

Mannan, M.A. 1999. Cash Waqf Certificate Global Opportunity the Sosial

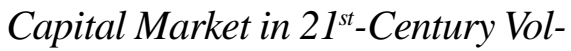
untary-Sektor Banking, Proceeding of the Third Harvard University Forum on Islamic Finance, Cambridge, Massachussets, Harvard University, 30 September-2 Oktober 1999.

Masyita, Dian. 2005. Sistem Pengentasan Kemiskinan yang Berkelanjutan Melalui Wakaf Tunai. Laporan Penelitian Kementrian Riset dan Teknologi RI. Jakarta.

Muhtada, Dani. 2007. Rekonseptualisasi Zakat Untuk Keadilan. Koordinator Lembaga Amil Zakat MIIAS (Masyarakat IslamAustralia Selatan)
2006-2007, Kandidat Doktor, AusAID fellow pada Flinders University Australia.

Rozalinda. 2013. Peran Wakaf Dalam Pemberdayaan Ekonomi Perempuan. Kamis, 30 Mei 2013, http://bwi.or.id, akses 5 Juli 2013.

Republika. 2003. Potensi Zakat Masyarakat Belum Tergali. Jumat, 11 Juli 2003, http://pkpu.or.id/lite/article/ potensi-zakat-masyarakat-belumtergali, akses 5 Juli 2013

Tambunan, Tulus. 2012. Usaha Mikro Kecil dan Menengah di Indonesia: Isu-isu Penting. Penerbit Pustaka LP3ES. Jakarta.

Yulianti, Rahmani Timorita. 2008. Peran Lembaga Keuangan Publik Islam Dalam Pemberdayaan Ekonomi Masyarakat. Millah Jurnal Studi Agama Vol. VIII, No.1 Agustus 2008. 
